\title{
Locally-Based Enterprise Training to Improve The Economic Empowerment of The Learners
}

\author{
${ }^{1}$ DAYAT HIDAYAT, ${ }^{2}$ ASEP SAEPUDIN \\ ${ }^{1}$ Program Studi Pendidikan Luar Sekolah F KIP Universitas Singaperbangsa Karawang \\ (UNSIKA), JIn. HS. Ronggowaluyo Telukjambe Timur Karawang \\ 2 Departemen Pendidikan Luar Sekolah (PLS) FIP Universitas Pendidikan Indonesia \\ JI. Dr. Setiabudhi No. 229 Bandung Jawa Barat \\ emal: ${ }^{1}$ dayathidayat194@yahoo.com, 2 aspudin@gmail.com
}

\begin{abstract}
Entrepreneurial skills of the learners of Independent Enterprise Literacy at Community Learning Center (CLC) Harapan Karawang Regency in developing locally-based enterprise, is still low. This study is aimed to analyze the planning, the implementation, the outcome, and the impact of locally-based enterprise training on improving the economic empowerment of the learners of Independent Enterprise Literacy. The approach uses in this study is a qualitative case study method. The subjects consist of four learners, a trainer, and an administrator of CLC. The data are obtained through the observation, in-depth interview, and documentation analysis. The data analysis involves the following stages: data collection, data reduction, data display, and conclusion drawing/verification. The locally-based enterprise training is designed through proper planning with the identification of learner needs, formulating objectives and preparing training curriculum that meets the needs and characteristics of the learners. The implementation of the training is conducted properly in accordance with a predetermined plan. The results of training assessment show an increase of knowledge, attitudes and behavior of learners' entrepreneurial skills. The enterprise training gives impact and influence to increase the learners' economic empowerment proved by the increasing income and wider business opportunities.
\end{abstract}

Keywords: enterprise training, locally-based, learners' empowerment

\section{Introduction}

Community development is essentially aimed at the development and improvement of socio-economic capabilities of society so that the center of gravity for community development process always refers to the direction of the creation of socio-economic conditions that continue to develop on the basis of the nature and principles of community development. Therefore, the economic, social, cultural, and political development becomes the main foundation of the community development, giving an indication that the process of society development can not be separated from the principles contained in the improvement of socioeconomic conditions.

The fundamental problem in the economic development of community in Indonesia is the economic structure of agrarian centric. Most of the population are still highly unskilled, having low income, (both in terms of per capita income and national income), economic growth is lower than the growth which of population, and low managerial ability technology. These problems are a major trigger for the interests of businesses in community development. In other words, the reference model of development, the importance of community development can not be separated from the issues of economic, social, and cultural communities.

The process of mobilization in community economic development is a process of mobilizing and directing all the power and funds available in the community for the benefit of social development concerned. Mobilization of individual potential generally showed in significant activity. It is because the numbers are $a$ few, not as much strength as a

Received: July 19, 2016, Revision: August 30, 2016, Accepted: December 19, 2016

Print ISSN: 0215-8175; Online ISSN: 2303-2499. Copyright@2016. Published by Pusat Penerbitan Universitas (P2U) LPPM Unisba Accredited by DIKTI. SK Kemendikbud, No.040/P/2014, valid 18-02-2014 until 18-02-2019 
mobilized group. Therefore, it is a necessary to take motivational stages that will build a mobilization. This mobilization ultimately uses a method called Community Organization (CO), which is a process to cooperate in a group holding direct identification of needs and resources in the community of Nonformal and Informal Education Program paid great attention to the needs of society as well as the identification of needs carried out by the community itself. Non-Formal and Informal Education Program claims that education programming is best rooted in and aimed to meet the needs of a particular society. Nonformal and Informal Education Program learning strategy, learning resources do motivation to prepare learners to participate learning objectives, learning materials and steps need to be taken in learning activities. In the implementation of the Nonformal and Informal Education Program, the method used to make people come together in a group, make up a potential force in addressing the problem or meeting the need they discovered and defined, as a unity of empowering people's economy based on local potential for residents to learn is through Independent Enterprise Literacy program.

Problems of economic empowerment of citizens to learn Independent Enterprise Literacy at CLC Harapan are a lack of knowledge, attitudes and entrepreneurial skills to develop their business. Entrepreneurship training program is an effort to increase knowledge, attitudes, and entrepreneurial skills people learn at Independent Enterprise Literacy so as to empower themselves, especially on the economic aspect.

The program of Independent Enterprise Literacy group is directed to increase community participation in spare time to increasing family incomes through learning and trying. Independent Enterprise Literacy Program fosters the stability of the preservation of basic literacy and increases family income as well as a forum of learning and skills upgrading of productive economic activities of the family. In addition, the Independent Enterprise Literacy gives benefit to raise social concern in developing a working partnership of strong economic entrepreneurs helping weak entrepreneurs to develop independent economic institutions of rural communities. Therefore the existence of Independent Enterprise Literacy continues to be developed and improved in order to really be able to act as a strong vehicle for the economic empowerment of the family.
Entrepreneurship training for residents to learn Independent Enterprise Literacy is a process of interaction between the raw input, instrumental input, environmental input, the process, output, influence, and other inputs. All components interact in entrepreneurship training phases, including planning, implementation, assessment, outcome, and impact on the economic empowerment of family of Independent Enterprise Literacy learners.

Based on the rationale above, the focus of this research includes the planning, implementation, results and impacts of the economic empowerment of citizens to learn Independent Enterprise Literacy after involving in locally based enterprise training at CLC Harapan, District of Cilamaya Kulon, Karawang regency.

Flow of the framework which becomes the background to conduct a research related to locally based enterprise training in enhancing the economic empowerment of citizens to learn Independent Enterprise Literacy at CLC Harapan district of Cilamaya Kulon, Karawang regency is considered successful enough so that can compete for harnessing local potential in developing the type of business.

Studies discussed are the theory relating to (1) training as one unit of Nonformal Education (2) entrepreneurship, and (3) community empowerment. Noe, Hollenbeck, Gerhart and Wright (2003: 251) argues that training is a planned effort to facilitate the learning of job related knowledge, skills, and behavior by employe. It means that training is an effort that is planned to facilitate learning about the work related to the knowledge, skills and behavior by employees. Training is defined as teaching or giving the experience to develop behavior (knowledge skill/skills and attitudes) in order to achieve something desired (Robinson, 1981: 12). Ontologically, the notion of training has been formulated by experts, including by Friedman and Yarbrough (1985: 4) in Sudjana, D. (2007:4) which argues that: "Training is a process used by organizations to meet their goals. It is called into operation when a discrepancy is perceived between the current situation and a preferred state of affairs. The trainer's role is to facilitate trainee's movement from the status quo toward the ideal."

Michael J. Juicus (1972) in Kamil, M. (2010: 3) asserts: "The term training is used here to indicate any process by which the 
attitudes, skills, and abilities of employees to perform specific jobs are increased." Training term used here is to show every process to develop the talents, skills and abilities of employees to complete certain jobs. From these definitions in mind that training related to certain jobs.

Entrepreneurial science is a discipline that studies on values, skills (abilities) and behavior in the face of life's challenges to pursue opportunities with the various risks that may be encountered. In a business context, Thomas W. Zimmerer (1996) in Suryana (2007:2) argues that "entrepreneurship is the result of a disciplined, systematic, process of applying creativity and innovations to the need and opportunities in the marketplace". Entrepreneurship is the result of a disciplined, systematic process in the application of creativity and innovation in meeting the needs and opportunities in the market.

John Kao (1991: 14) in Sudjana, D. (2004: 131) argues that "entrepreneurship is the entrepreneurial attitude and behavior. An entrepreneur is a person who is innovative, anticipatory, initiative, risk-taking and profitoriented. "This means that entrepreneurship is an attitude and behavior of people who are innovative, anticipatory, initiative, risk-taking and profit-oriented.

According to Peter F. Drucker (1994) argued that entrepreneurship is the ability to create something new and different (ability to create the new and different). Even in a simple way, entrepreneurial is defined as the ability of entrepreneurs (Ibn Soedjono, 1993; meredith, 1996; Marzuki Usman, 1997 in Suryana, 2007: 4). Entrepreneurship is a translation of "entrepreneurship", which can be interpreted as "the backbone of economy", ie the nerve center of the economy or as a tailbone of economy', ie controlling the economy of a nation (Soeharto Wirakusumo, S. 1997: 1 in Suryana, 2007: 4). Etymologically entrepreneurship is the value required to start a business (start-up phase) or a process of doing a new (creative) and something different (innovative).

Empowerment is derived from the word "power" means the capacity/ ability. The term empowerment can be attributed to the transformation of the social, economic and political (power). Soetomo (2011: 65) argues that the recent developments established itself as a community development approach that is widely used in a variety of community development policy. This approach is in many ways can be seen as operationalization of perspective or paradigm of community development.

The concept of empowerment in community development discourse is always associated with the concept of independence, participation, networking, and justice. Basically, empowerment is put on the individual and social strength. According to Rappaport (1987) in Wisdom, H. (2010: $3)$. stated that empowerment is defined as understanding the psychological effects of individual control on the social, political powers and rights under the law. Meanwhile, McArdle (1989) in Wisdom, H. (2010: 3). Defines empowerment as a process of decision-making by people who consistently implement the decision.

In an effort to increase awareness and the ability of the world occupied by young people as part of the community, in accordance with the proposed educational awareness Freire, Suzanne Kindervatter in his book Nonformal Education as an Empowering Process (1979) put forward the concept of empowerment or empowering process. This concept means that "People gaining an understanding of and control over social, economic, and political forces for in order to improve reviews their standing in society." The process of giving strength or empowerment is any educational efforts aimed at raising awareness, understanding, and sensitivity of learners to the development of social, economic and/or political, so that learners have the ability to repair and improve the status of social, economic and political in their society.

The purpose of this study is to analyze the planning, implementation, results and impact of locally based enterprise training in enhancing the economic empowerment of learners Independent Enterprise Literacy at CLC Harapan Village Sukamulya, District of Cilamaya Kulon, Karawang regency.

The benefits of this research are: (1) theoretically as input to develop a theory that relevance to the activities of similar problems, especially on the implementation of the program of community empowerment through entrepreneurship training. This study becomes a means of developing academic skills for the implementation of programs Nonformal and Informal Education Program broader; (2) practically, this research becomes the input for the board of CLC Harapan in developing entrepreneurship training program to run properly and achieve 
more optimal results.

\section{Methods}

The approach used in this study was a qualitative case study method. This method was designed and used to describe and analyze the facts with the correct interpretation of the entrepreneurship training activities based on local potential in enhancing the economic empowerment of Independent Enterprise Literacy learners in CLC Harapan Village Sukamulya, district of Cilamaya Kulon, Karawang regency. Subjects were selected "purposively (according to destination)." Nasution (1996: 11) states that "naturalistic method does not use random sampling or random, nor use a large sample." In this study, the subjects were six people consisting of four villagers learning Independent Enterprise Literacy, an administrator and a trainer of Harapan CLC entrepreneurship.

Data collection techniques used in this study include observation, in-depth interviews (depth interview), and analysis of data about the documentation to describe the planning, implementation, results and impact of locally based enterprise training in enhancing the economic empowerment of citizens to learn Independent Enterprise Literacy. Stages of the research were conducted through the following steps: the orientation phase, exploration and member check (Nasution, 1996:33-34). To analyze the research data conducted, it is in accordance with an interactive model of Miles and Huberman (1992: 20), which include: (1) the data collection; (2) data reduction; (3) data display; and (4) conclusion, drawing verifying.

\section{Planning of the Entrepreneurship Training}

Conceptually, this locally-based enterprise is based on the framework of philosophy, psychological, and sociological that envisages the need for change in delivery of training by growing empowerment and strengthening of entrepreneurial competencies learners of Independent Enterprise Literacy. The development of this training model is based on the learning oriented to the needs of adults (adult education), research on the human brain, the model Lazanov, innovation modern approaches such as accelerated learning and learning quantum (Sumpeno, W. 2009: 46).

For the implementation stages of entrepreneurship training is in line with the opinion of Sudjana, D. (2007: 31)

who argued that the typical characteristics of Nonformal and Informal Education Program training program is a structure that is flexible and approach to democratic start planning, implementation, and evaluation of the feedback.

The plan of locally-based enterprise training in learning Independent Enterprise Literacy citizens was through various stages initiated with the identification of training needs of entrepreneurship. Identification of training needs was carried out to locate and determine the entrepreneurial training needs required by the learners to learn. The analysis used is training needs assessment, to gather information and determine the training required or not by the learners. Needs analysis was carried out systematically and objectively to determine: (1) model of entrepreneurship training needs; (2) the material required training and entrepreneurial competence to be achieved; and (3) formulate strategies, methods and media training: and (4) the assessment system used to measure the success of entrepreneurial training.

Analysis of the needs of the learners was performed before the design of entrepreneurship training activities has been set. Its activities include training needs analysis and assessment of learners' in entrepreneurship and entrepreneurship training process analysis. Through studies of this needs analysis, it will be able to determine the appropriate model of entrepreneurship training and entrepreneurial training materials which are appropriate to enhance the entrepreneurial competencies of the learners Independent Enterprise Literacy.

The conditions above are in line with the opinion of Atmodiwirio, S. (2002: 88) which argues that the objective of learning needs analysis of learners to the development of entrepreneurial training is to: (1) describe the true nature of a discrepancy execution of work; (2) determine the causes of discrepancy execution of the work; (3) to recommend appropriate solutions; (4) to describe the potential trainees.

Thus, the needs analysis was conducted to determine the knowledge, attitudes, skills, needs, desires and motivations which are actually owned by the learners to follow entrepreneurial training. During this activity, the trainers motivate and increase the intensity of communication with learners in order to obtain clarity, that learners will actually follow entrepreneurial training 
program in earnest. Material assessment process include: (1) the background of the learners training in entrepreneurship; (2) the various potentials of the learners and be connected to the real needs of the learners in participating in the training process; 3 ) the background of the lives of learners in the community and at home; (4) environmental conditions of learners where they live and work; and (5) the conditions of learners in daily life. The identification is done to help solve the problems through a process of training and strategies implemented primarily in choosing designs and themes that match the entrepreneurship training materials designed.

Assessment results can be used as a reference in preparing training plans, the establishment of a training strategy, training methods and teaching materials (resources) for learner to use. It is intended in order to: (1) the learners to have a sense of responsibility towards entrepreneurship training program for the sustainability and success of the Independent Enterprise Literacy program; (2) involvement of the learners in preparing the training plan is the first step in the process of training; (3) search and analysis needs of the learners will be discovered early, so as to facilitate trainers in developing a training program especially; training materials, strategies and methods of training and training evaluation model that will be developed as well as knowledge, attitudes and entrepreneurial skills that match the need and needs of the learning material; and (4) the involvement of learners in the planning of learning can facilitate the training of trainers to analyze the problems posed and facilitate solution of problems found in the training process and to measure the success of the training. The results of the activities identified above are expected to increase the participation of the learners in the training process thereby increasing confidence in the entrepreneurial training continuously.

The overview of entrepreneurship training for Independent Enterprise Literacy learners in line with the opinion of Soetomo (2011: 65), which suggests that the approach to the analysis of the programs implemented in the public communities to the bottom level community gave the opportunity and authority in the management of development including the decision-making process since the identification of the problem and needs, planning, implementation, evaluation, and to benefit the development.
The next stage is the preparation of curriculum and training materials formulation. The preparation and formulation of training objectives were implemented to obtain the concepts and implementation of entrepreneurship training sharper and comprehensive, structured entrepreneurial training curriculum. Entrepreneurship training curriculum need to pay attention to the characteristics of the learners. Development of training materials used tailored to the abilities and potential of each group of learners. Development of training materials created in the form of training modules were integrated, comprehensive, and synchronization. Integrative, meaning that the preparation of training modules correlated to each other entrepreneurship among the components in the sessions entrepreneurship training materials. Comprehensive means that entrepreneurship training materials, depth of content tailored to potential learners. Synchronization means that entrepreneurship training materials appropriate for the characteristics of the learners.

Development of training materials designed in the entrepreneurial training module arrives digestible, the language used is simple. The use of language and concepts for the development of entrepreneurial training was specifically designed in accordance with the social and cultural potential learners. The existence of the syllabus, Unit Training Event and training modules are an important element in the preparation of curriculum and training materials entrepreneurship. These three elements are as stated essentially an elaboration of the curriculum. Syllabus, Unit Training Event and modules were used as guidance by trainers with developmentoriented adjustment to the condition of learners, facilities, and trainers carrying out the task given in entrepreneurship training.

In developing material locally-based enterprise training, Sudjana, D. (2004: 34) states that the use of natural resources and the environment is very helpful in the learning process. These sources include: (1) human resources: (2) natural resources; (3) cultural resources; and (4) technological resources. Human resources are important asset to take advantage of other resources in the learning activities, including the development of an entrepreneurial society. Human resources become a major supporting factor that can take the learning process to the maximum so as to improve the welfare of the community 
Furthermore, Arsyad, L. (2011: 95) argues that entrepreneurship development strategies that based on local potential emphasize the promotion of economic growth driven by the local community by utilizing local potentials for development in an effort to improve the economic well-being of local communities. The entrepreneurship development strategy uses a territorial approach that relies primarily on the needs, potential, and local actors of a certain area (locality).

\section{Implementation of the Entrepreneurship Training}

During the implementation phase of training for residents to learn Independent Enterprise Literacy at CLC of Harapan entrepreneurial material was presented with the general pattern of the composition of entrepreneurship training; 30\% theory, 70\% practice and implementation. The theory is done in the classroom or in other rooms beginning with pre-test at the first meeting and post test (over all evaluation) at the last meeting. Practice and implementation of entrepreneurship portion with a composition of $70 \%$ while $40 \%$ was carried in and out of the classroom or another room, but was still in the CLC, and outside the theoretical training hours.

The frequency of meetings was according to the type of practicum and scheduled from the beginning so that everything related to the lab have been prepared before $30 \%$ portion of the implementation phase is wholly outside the CLC or in the work environment of each learning resident. To evaluate the results and discuss the implementation it can be combined with a portion of lab time. This means that the lab could also be used to discuss the results of the training implementation. At this stage, clc organized the accompaniment with partners and business partners as a means of consultation for Independent Enterprise Literacy learners who experiencing problems that should be done at a particular time outside of learning hours, practice and implementation that has been set.

On the implementation of entrepreneurship training at CLC of Harapan, it involved various stakeholders, such as the chairman of the CLC, the chairman of each Independent Enterprise Literacy so that the script can be understood in the process of training. (1) Scenario entrepreneurship given by the Chairman of CLC and the group leader of Independent Enterprise Literacy to learners to understand the training scenarios entrepreneurship; (2) the Chairman of CLC Harapan recruited candidates for the trainer to set them to be assigned to train entrepreneurship for learners; (3) Chairman of the group of Independent Enterprise Literacy implemented entrepreneurship training cooperation with business and industry, banking and enterprise 'venture capital' of each of at least one business unit to become a partner of the group of Independent Enterprise Literacy; (4) do the preparatory meetings entrepreneurship training in group Independent Enterprise Literacy led by chairman CLC and attended by trainers, partners Independent Enterprise Literacy, workers and administrative personnel concerned. This preparatory meeting to produce a training schedule from the beginning to the final evaluation.

Implementation of entrepreneurship training in Independent Enterprise Literacy group was coordinated with partners, especially for the practice and implementation. In this case the entrepreneurship trainers and the parties involved in providing guidance and implementing entrepreneurship training syllabus, unit training event and modules. Implementation of entrepreneurship training concludes an evaluation of the learners. After implementing process, the assessment is a component to measure the success of the training process according to the indicators of success that has been established. In the evaluation, it is necessary to determine the criteria and tools used, in accordance with the purpose of training, which concerns with the knowledge attitudes and behavior of entrepreneurial skills. Further evaluation addresed to facilities, infrastructure as well as funds and other supporting devices, the indicator number and function. The parameter is very large and whether it is implemented or not based on the function. All indicators and the parameters are used to measure numerous training's elements should be operationalised, thus all aspects of the training can be assessed quantitatively and become the basis of compulsory analysis in the same way as qualitative analysis. Therefore, corrective measure can be certainly determined and implemented by training's factors which receive negative feedback and need repair.

The context of the theory of training in this research has the same vein with Robinson's point of view (1981: 12) that 
the training is teaching or giving experience to an experiencer for developing behaviour (knowledge, skills and attitude) in order to achieve precious something to be desired. Entrepreneurship training is dimensionalised to strengthen the local communities, it means the empowerment is not only process of delivering curiosity but also skills, and put more emphasis on efforts to improve knowledge, attitude, and the skills' selves. In the process of training it is expected to address or to overcome societies' problem in their lives. Training entrepreneurship as a process of economic empowerment emphasizes the crucial ability in scrutinizing each situation of economics, social, politics, and develop their own skills sustainability in order to improve their standard of living (Kindervatter, S. 1979: 12-13).

In the context of entrepreneurship training in enhancing the economic empowerment it, Riyanto, A. (2000: 5-6) argues that:

\begin{abstract}
Entrepreneurial training is a kind of education that teaches how to be able to create their own business activities. Such training was accomplished by means of: (1) build faith, soul and spirit; (2) build and develop the mental attitude and the nature of entrepreneurship; (3) develop the power of thought and how entrepreneurship; (4) to promote and develop the power of driving themselves; (5) understand and master techniques in the face of risk, competition, and a process of cooperation; (6) understand and master the ability to sell an idea; (7) have the management or processing capability, and (8) have particular expertise include foreign language acquisition for the purposes specified.
\end{abstract}

Furthermore Sudjana, D. (2004: 131) suggests that training as a unit Nonformal and Informal Education Program integrate the learning activities and strive, both in industry and trade and services, according to the needs of learners and the resources available in their environment, basically has touching guiding and entrepreneurship development. Entrepreneurship is very important for people, especially in the lower layers (the grass-root level), in the framework of the process of empowerment (empowering process) community in economics related to the social, cultural, political, and etc. Entrepreneurship is an alternative to increasing the competitiveness of Indonesian society in the era of globalization.

Nonformal and Informal Education Program foster and develop entrepreneurship through two approaches, namely: (1) integrate a subject matter of entrepreneurship into the curriculum/program in units and types of school education. Entrepreneurship can be a subject matter or added in family education, study groups, courses, and similar educational units, such as training, education, and apprenticeship center. Similarly, entrepreneurship can be integrated into general education, religious, official, office work, and vocational/skills; (2) Entrepreneurship is into its own education program. The program is conducted through educational of selfawareness (conscientization) for the society, and also can be in a special education unit form like learning group, course, training, and entrepreneurship apprentice. Thus, the entrepreneurship as an autonomous program can be done by education cadre, education people, and/or education expansion (Sudjana, D., 2004: 132).

\section{Behavior And Entrepreneurship Skill Learners}

The final result of entrepreneurship training for this Independent Enterprise Literacy learner is developing the new entrepreneurs who have the entrepreneur soul. Because that, "... entrepreneurship in a simple way is meant as a principle or a competence of entrepreneurship" Soedjono, 1993; Meredith, 1996; Marzuki, 1997 in Alma, B. 2007: 22). For more detail, Bygrave (1994: 1) as quoted Alma, B. (2004: 22) interpret this entrepreneur "... as the person who destroyed the existing economic order by introducing new products and services, by creating new forms of organization, or by exploring new raw materials." In the core entrepreneur is interpreted as the person who changes the economy order by knowing the result and service, making a new organization or digging the new raw materials. This means the entrepreneurship relates to someone's effort to fix the economy by product knowing, managing and digging the new resources for the economy need.

The result of the increasing of the Independent Enterprise Literacy learners' entrepreneurship competence after following the entrepreneurship training, is a raising of entrepreneurship knowledge on (1) companion entrepreneurship, which includes the knowledge about the entrepreneurship interpretation, the entrepreneurship result, the entrepreneurship characteristic, the entrepreneurship benefit, and the entrepreneurship target; (2) The effort planning, which includes the knowledge of production planning, the study of production 
properness, and the market chance; (3) The planning and controlling finances, which includes the knowledge about the planning of finances action, the finances counting towards the resource, the measuring and controlling strategy and finances outcome, success in finances part by the people, and the finances controlling tools by decision of information system; (4) The using of local resources, which includes the knowledge about the way to gain the local resources, evaluating the local market chance, distributing commodity and merit, using the resources from beyond, and cooperating with the government or private corporation.

The increasing of behavior aspect which is owned by the Independent Enterprise Literacy learners in developing efforts are (1) self-confidence, which is the merger of behavior and belief of the Independent Enterprise Literacy toward their learning task facing residents in their job. A learning resident who has had the self-confidence, he/ she has the belief about his or her ability to get his or her business success; (2) oriented in task and result, the learning residents who has the values of achievement motive, oriented towards the profit, perseverance, and fortitude, determination, hard work, has the strong encouragement, energetic, and has the initiative in doing his or her effort; (3) The braveness in taking the risk, that is the willingness and ability to take the risk in his or her run the effort; (4) Leadership, namely the ability in using his or her creativity and innovation in developing his or her effort. He or she always want to hangout to get the chance, open to criticism and suggestion which is used as the chance to develop her or his effort; (5) The originality, namely the innovative citizens who learn is a person who is really creative and believes in the new better ways to develop his or her effort. Residents will never feel satisfied with the ways which are done by him or her in developing his or her effort now, Although that way is good enough and always pour imagination in his or her job; and (6) Future oriented, namely the citizens learner who has had the perspective and a view to the future in doing his or her effort by looking for a chance to find the best partner who can develop him or her.

That entrepreneur behavior above is appropriate with Meredith, Geoffery G. et.al, (2005: 5-6)'s opinion who reveals the features entrepreneurs, as shown on Table 1. The improvement entrepreneurship skills for the learners of Independent Enterprise Literacy are as follows: (1) Managerial skill is a provision which has to be had by the entrepreneur. The learners as the entrepreneurs who are able to do the planning, organizing, moving, and controlling functions reach the desirable goal; (2) Conceptual skill, i.e., the learner residents who have the ability to formulate the goals, policies and business strategy are the main foundation towards a successful entrepreneur; (3) Human skill, i.e., the ability to be outgoing, sociable, have the sympathy and empathy to the others as a business partner. These capability becomes the capital-skill that is highly supportive of the entrepreneurs towards business success; (4) Decision-making skill, i.e., the ability to analyze the situations and formulate various problems to be looked for various alternative solutions in operating their effort; (5) Time managerial skill, i.e., managing the time can facilitate the execution of the work and plans of business that is being run by them.

A successful entrepreneur usually has the competence of knowledge, skills and quality of the individual that includes attitudes, motivations, values and behavior which is necessary to do the work/ activities.

Table 1

The Features And Characteristic of Entrepreneurs

\begin{tabular}{|l|l|}
\hline \multicolumn{1}{|c|}{ Features } & \multicolumn{1}{c|}{ Characteristic } \\
\hline Self-confidence & $\begin{array}{l}\text { Confidence, independence, individuality } \\
\text { optimism } \\
\text { Oriented tasks and result } \\
\text { determination, hard work, have a strong encouragement, } \\
\text { energetic, and initiatives } \\
\text { The ability to take risks, like the challenge } \\
\text { Tehes the risk } \\
\text { Leadership }\end{array}$ \\
Future orientation & $\begin{array}{l}\text { suggestions and criticisms } \\
\text { Foresight and perceptive }\end{array}$ \\
\hline
\end{tabular}

Source: Meredith, Geoffery G. et.al, 2005:5-6 
The skills that must be possessed by Suryana (2007) are as follows: (1) Managerial skills (managing skills); (2) Conceptual skills (skills draft); (3) Human skill (skill to understand, communicate and relate); (4) Decision making skills (skills to formulate problems and make decisions), and (5) time managerial skills (skills in organizing and using time).

\section{Economic Empowerment Impact of The Independent Enterprise Literacy of Learner}

The impact of locally-based entreprise training in enhancing the economic empowerment of the learners of Independent Enterprise Literacy at CLC Harapan showed good results. The impact of the entrepreneurship training can enhance the employment opportunities then it can reduce the unemployment, increase the labor productivity which is implicated to the learning residents income.

The perceived impact for the learning residents after following the training entrepreneurial venture can develop the mushroom cultiration as a featured business on its territory. This condition certainly has an impact on increasing the learners' income.

Epistemologically, locally-based entreprise training for economic empowerment of the Independent Enterprise Literacy learners is a develope model approach system (Sudjana, D. 2007: 4). The entrepreneurship training components include the raw input, instrumental input, environmental input, and other inputs. Processes training is a learning interaction between the input means, especially a coach, with trainees as raw input. The purpose of training consists of learning objectives between the output, and the final learning objective, i.e., the effect (outcome). The influence relates to the benefits or usefulness of training that they have trained for himself, institutions, communities, etc.

In short, the training program will be closely linked with the elements of training which are organized systemically, i.e., load components, processes and training purposes.

In the results of the research related to the program of Entrepreneurship Education Society which is done a lot. The results showed that entrepreneurship education that has been carried out is one of the important factors to grow and develop a passion, spirit and entrepreneurial behavior among the public. The results of research conducted by Saepudin, A., Ardiwinata, J.A., and Sukarya, Y. (2014) concluded that training can effectively improve self-efficacy and behavior of entrepreneurship in society at CLC transition period Jelita Bandung regency.

\section{Conclusions}

The planning of the training is done through the identification of learning need, fostering familiarity, formulating the goals, arranging the program and material for the entrepreneurship training. CLC administrators and coaches as a learning resource help the learning residents to identify the necessary resources, learning materials, aids, and other supporting factors like curricula and training materials that were prepared in to meet the learning needs and characteristics of the Independent Enterprise Literacy learners.

On the implementation of training, learning resources motivate learners to develop various potentials to develop their business. Learning resources help residents learn mutual business experience with residents to learn more. Training materials entrepreneurship theory and practice were given inside or outside the classroom environment of CLC, including the work environment of each citizen to learn. In the implementation, mentoring was done with partners and business partners of CLC. The final stage of training was the implementation of assessment through experience turning pedestals learners skills for studying and trying.

Training results showed an increase of knowledge, attitudes and entrepreneurial skills the learners of Independent Enterprise Literacy. In the aspect of knowledge, the learners have to have knowledge about the meaning, purpose, characteristics, benefits, and entrepreneurial goals. Learners learn to know business planning, financial control, and the use of local resources. In the aspect of attitude, learners begin to have an entrepreneurial attitude and behavior shown by the growing sense of confidence in his ability to achieve success. In the aspect of skill, learners have the skills to manage, communicate and relate to the business, as well as set up and use the time for doing business.

The impact of entrepreneurial training activities showed an increase in learners' income for developing their business.

Based on the findings, several 
suggestions are given as follow:

CLC administrators in the planning of the training should manage the preparation of entrepreneurial training curriculum and materials in accordance with the local potential so that learners can increase their participation according to their respective capabilities.

CLC administrators in the implementation of training should conduct broader cooperation with parties such as industrial companies, banks, government and private institutions to expand business opportunities for the learners of Independent Enterprise Literacy.

CLC administrators should help the Independent Enterprise Literacy learners to apply the working capital loans to the government and private bank with low interest to add capital to run their business. In addition, the administrators also should help distribute the Independent Enterprise Literacy learners' product in developing their business.

\section{Reference}

Alma, B. (2007). Kewirausahaan. Bandung: Alfabeta.

Arsyad, L., Elan, S. Dkk. (2011). Strategi Pembangunan Perdesaan Baerbasis Lokal. Yogyakarta: UPP STIM YKPN.

Atmodiwirio, S. (2002). Manajemen Pelatihan. Jakarta: PT Ardadizya Jaya.

Drucker, P. F. (1994). Innovation and Entrepreneurship, Practice and Principle. New York: Harper Business.

Hikmat, H. (2010). Strategi Pemberdayaan Masya rakat. Bandung: Humaniora Utama Press.

Kamil, M. (2010). Model Pendidikan dan Pelatihan (Konsep dan Aplikasi), Bandung Alfabeta.

Kindervatter,S. (1979). Nonformal Education as An Empoworing Process. Massachusetts: Center for International
Education University of Massachusetts.

Miles, Matthew B.dan Huberman, Michael A. (1992). Analisis Data Kualitatif. Jakarta: UI Press.

Nasution. (1996). Metode Penelitian Naturalistik Kualitatif. Bandung: Tarsito. Noe, Hollenbeck, Gerhart, Wright (2003) Human Resource Management, International Edition. New York: The McGraw-hill Companies Inc. .

Meredith, Geoffery G. (2005). Kewirausahaan, Teori dan Praktik, Seri Manajemen StrategisNo. 1. Jakarta: PT. Pustaka Bimanan Pressindo.

Riyanto,A.(2000). Kapita Selekta Kewirausahaan. Bandung: Yapemdo. Robinson, K. P. (1981). A Handbook of Training Management. London: Kogan Page Ltd.

Saepudin, A., dkk. (2015). Efektivitas Pelatihan dan Efikasi Diri dalam Meningkatkan Perilaku Berwirausaha pada Masyarakat Transisi. Jurnal Mimbar: Sosial dan Pembangunan. Volume 31, Nomor 1, Juni 2015.

Soetomo. (2011). Pemberdayaan Masyarakat, Mungkinkah Muncul Antitesisnya?. Yogyakarta: Pustaka Pelajar.

Sudjana, D. (2007). Sistem dan Manajemen Pelatihan, Teori dan Aplikasi. Bandung: Falah Production.

Sudjana. (2004). Pendidikan Nonformal, Wawasan, Sejarah Perkembangan, Falsafah,Teori Pendukung, Azas. Bandung: Falah Production.

Sudjana, (2004). Manajemen Program Pendidikan, untuk Pendidikan Nonformal, dan Pengembangan Sumber Daya Manusia. Bandung: Falah Production.

Sumpeno, W. (2009). Sekolah Masyarakat, Penerapan Rapid-Training Design Dalam Pelatihan Berbasis Masyarakat. Yogyakarya: Pustaka Pelajar.

Suryana. (2007). Kewirausahaan, Pedoman Praktis Kiat dan Proses Menuju Sukses. Jakarta: Salemba Empat. 